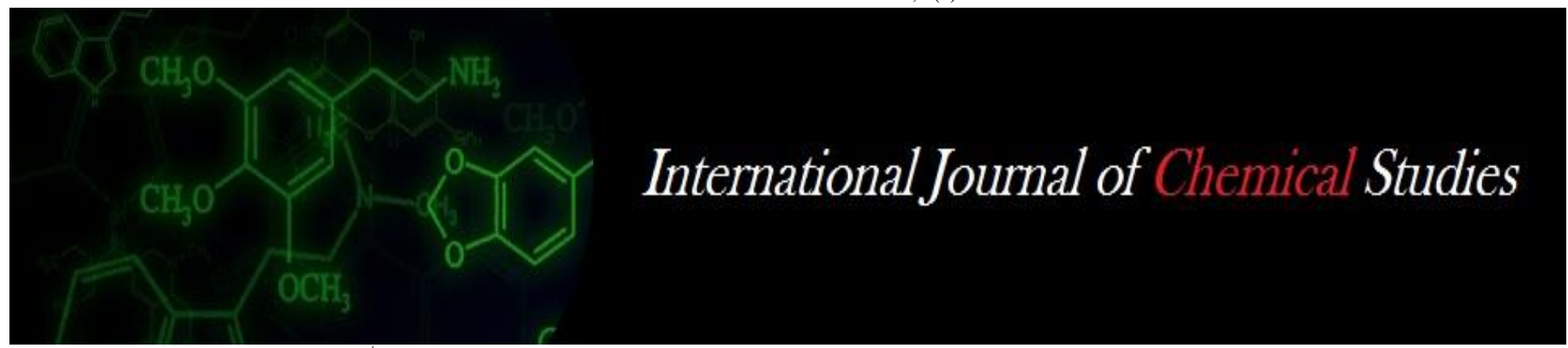

P-ISSN: 2349-8528

E-ISSN: 2321-4902

www.chemijournal.com

IJCS 2020; 8(4): 3365-3369

(C) 2020 IJCS

Received: 23-05-2020

Accepted: 24-06-2020

Sneha Kumari

Department of Agronomy,

I.A.S., Banaras Hindu

University, Varanasi, Uttar

Pradesh, India

Manoj Kumar Singh

Department of Agronomy,

I.A.S., Banaras Hindu

University, Varanasi, Uttar

Pradesh, India

Sripriya Das

Department of Agronomy,

I.A.S., Banaras Hindu

University, Varanasi, Uttar

Pradesh, India
Corresponding Author: Sneha Kumari

Department of Agronomy,

I.A.S., Banaras Hindu

University, Varanasi, Uttar

Pradesh, India

\section{Studies on mulching and weed management in unpuddled transplanted rice (Oryza sativa $\mathrm{L}$.)}

\author{
Sneha Kumari, Manoj Kumar Singh and Sripriya Das
}

DOI: $\underline{\text { https://doi.org/10.22271/chemi.2020.v8.i4ap.10173 }}$

\begin{abstract}
A field experiment was conducted during kharif season of 2017 and 2018 at Institute of Agricultural Sciences, BHU, Varanasi. The experiment was laid out in a split plot design with three mulching treatments, viz. no mulching, cover crop of Sesbania followed by green mulch and rice residue mulch (5 t/ ha) in main plots and five weed management treatments, viz. weedy, two hand weeding, postemergence application of bispyribac Na $25 \mathrm{~g} / \mathrm{ha}$, penoxsulam $30 \mathrm{~g} /$ ha and tank mix bispyribac Na $25 \mathrm{~g} /$ ha + pyrazosulfuron $20 \mathrm{~g} / \mathrm{ha}$ at 18 DAT in sub plots replicated thrice. The results revealed that cover crop of Sesbania followed by surface mulch followed by green mulch and rice straw mulch recorded significantly higher growth attributes, yield attributes and production efficiency as compared to no mulching. Among weed management treatments post-emergence application of penoxsulam $30 \mathrm{~g} / \mathrm{ha}$ resulted in significantly higher growth and yield attributes as compared to weedy and increased production efficiency followed by spraying of bispyribac $25 \mathrm{~g} / \mathrm{ha}+$ pyrazosulfuron $20 \mathrm{~g} / \mathrm{ha}$ and postemergence spraying of bispyribac $25 \mathrm{~g} / \mathrm{ha}$.
\end{abstract}

Keywords: Cover crop, mulching, post-emergence, rice straw, unpuddled transplanting

\section{Introduction}

Rice (Oryza sativa L.) is one of the most important food crops in the world and is consumed by more than 3 billion people (Fageria, 2007) ${ }^{[3]}$. In India, rice (Oryza sativa L.) is one of the most important cereal crop of kharif season and the staple food of 2.7 million people of the eastern and southern parts of the country. It is estimated that, by the year 2025, it will be necessary to produce about $60 \%$ more rice than currently produced to meet food needs (Fageria, 2007 GRISP, 2013) ${ }^{[3,5]}$. Transplanting in puddled soil is the most dominant and traditional method of establishment in rice. Puddling of soil before transplanting rice (Oryza sativa) helps to suppress weeds during crop establishment but this practice is tedious, costly, time and energy consuming (Gill et al., 2014) ${ }^{[4]}$. On the other hand, non-puddled transplanting is an emerging option to overcome these problems (Haque et al., 2016) ${ }^{[6]}$ and also reduce cost of rice cultivation (Islam et al., 2014) ${ }^{[8]}$. With the development of resource conserving technologies, unpuddled transplanting is being emerged as a viable alternative to puddled transplanted rice. Crop under unpuddled transplanting faces severe weed infestation due to less tillage and lack of submergence at the time of transplanting. Rice straw is a good organic mulch material for weed management it remains on soil surface, undecomposed for longer period of time (due to presence of ligno-cellulosic materials). Moreover, incorporation of cover crop into the soil may add allelochemicals to the soil to prevent germination and establishment of weeds (Buhler, 2002) ${ }^{[2]}$. Use of appropriate one shot early post-emergence herbicides in could provide good control on weeds in unpuddled transplanted system and helps achieve high yield with higher net benefit over weed free plots (Rahman, 2016) ${ }^{[11]}$. In order to devise a sustainable weed management strategy for unpuddled transplanted rice, studies need to be done on the mulching in combination with herbicides. Since not much work has been done in this field, this research is designed to address the problem of making unpuddled transplanted rice popular among farmers.

\section{Materials and Methods}

The field experiment was conducted in kharif 2017 and 2018 at Agriculture Research Farm, Institute of Agricultural Sciences, BHU, Varanasi. Geographically farm is located at an 
altitude of $75.7 \mathrm{~m}$ above the mean sea level in the Northern Gangetic alluvial plains, $25^{\circ} 18^{\prime} \mathrm{N}$ latitude, $88^{\circ} 03^{\prime} \mathrm{E}$ latitude. The site of the experimental field remained same during both the years of investigation. The experimental field was homogeneous in fertility with even topography and typically a mid-land, suitable for rice crop cultivation during kharif season, uniform textural make up having assured irrigation. The experiment was laid out in a split plot design with three mulching treatments viz., without mulching, cover crop of Sesbania followed by surface mulch with same residue and rice straw mulch $(5 \mathrm{t} / \mathrm{ha})$ in main plots and five weed management treatments, viz., weedy, hand weeding at 20 and 40 DAT, post-emergence application of bispyribac $25 \mathrm{~g} / \mathrm{ha}$ at 18 DAT, post-emergence application of penoxsulam $30 \mathrm{~g} / \mathrm{ha}$ at 18 DAT and post-emergence application of bispyribac 25 $\mathrm{g} / \mathrm{ha}$ and pyrazosulfuron $20 \mathrm{~g} / \mathrm{ha}$ at $18 \mathrm{DAT}$ in sub plots. Sesbania was sown as a cover crop, 35 days before the transplanting with the row spacing of $25 \mathrm{~cm}$ at seed rate of 25 $\mathrm{kg} / \mathrm{ha}$ and incorporated manually at the time of transplanting and rice straw mulching ( $5 \mathrm{t} / \mathrm{ha}$ ) was done after transplanting as per treatment. The experimental field was under a ricewheat system. All crop residues were removed at ground level at the time of harvest. Rice variety "Arize-6444" seed was sown as per respective treatments. A seed rate of $18 \mathrm{~kg} / \mathrm{ha}$ was used for nursery raising of the crop. Nursery raising of seedlings were done by dry bed method. Well pulverized raised nursery beds were prepared. The pre-soaked seeds were sown in the raised nursery bed by kudal manually at a $25 \mathrm{~cm}$ row to row spacing. After one pass strip tillage followed by inundation of the land up to $3-5 \mathrm{~cm}$ of standing water for 48 hours to make the land sufficiently soft for transplanting (Haque et al. 2016) ${ }^{[6]}$, finally transplanting of seedlings were carried out. Eighteen days old seedlings were transplanted in the field at 2 seedlings per hill at spacing of $20 \mathrm{~cm} \times 15 \mathrm{~cm}$. Flexible wire rope and colored cloth strips were used at specific interval as per the desirable spacing for maintaining the distance between plant and rows during transplanting operation.

Uniform dose of nitrogen at the rate of $140 \mathrm{~kg} / \mathrm{ha}$ was applied through Urea $(46 \% \mathrm{~N})$, in three equal splits, at One-third dose of nitrogen, was applied as basal, remaining nitrogen was applied in two equal splits during active tillering (30 DAP) and panicle initiation stage (65 DAP) respectively. Entire dose of $\mathrm{P}_{2} \mathrm{O}_{5}(60 \mathrm{~kg} / \mathrm{ha})$ in the form of Single Super Phosphate and $\mathrm{K}_{2} \mathrm{O}(60 \mathrm{~kg} / \mathrm{ha})$ through Muriate of Potash along with $62.5 \mathrm{~kg} \mathrm{ZnSO}_{4}$ /ha (Zinc sulphate heptahydrate 21 per cent) were applied at the time of field preparation as basal dose. Sowing of Sesbania was done at 45 days before transplanting at the rate of $25 \mathrm{~kg} / \mathrm{ha}$ with $25 \mathrm{~cm}$ row spacing and incorporated manually at the time of transplanting. Residue of Sesbania was used as surface mulch between the rows of transplanted rice. Rice straw mulching was done after transplanting between the rows@ 5 t/ha. Weed control treatments were applied in the plots as per the treatments. Two weeding in the hand weeded plots were done manually at 20 and 40 days after transplanting. Weedy plots remained infested with native weed population till harvest of the crop. Herbicides were applied as aqueous medium at the rate of 500 liters water/ha with help of knapsack with flat fan nozzle. The amount of herbicides and water required was computed on the basis of gross plot size to be treated. Bispyribac-Na (25 g/ha), penoxsulam (30 g/ha) and bispyribac-Na (25 g/ha) + Pyrazosulfuron ethyl (20 g/ha) were applied at 18 days after transplanting (as post-emergence) as per the treatments.
The crop was harvested manually in second fortnight of October 2017 and 2018 when panicles were nearly ripe and straw had turned yellow. After manual threshing, grain yield was recorded after separating from the straw by winnowing. The data on plant height, number of tillers $/ \mathrm{m}^{2}$, panicle length, test weight, was recorded from randomly selected ten plants in the plot. The harvested crop was threshed manually. Production efficiency in terms of $\mathrm{kg} / \mathrm{ha}$ /day was determined by dividing the yield to the number of days to maturity of each treatment separately.

The sample of rice grain, straw and weeds were collected at harvest, dried in sun and then oven dried. The samples were ground and sieved through $0.5 \mathrm{~mm}$ sieve. The required quantity of samples was weighed out accurately and was subjected to acid extraction to determine $\mathrm{N}, \mathrm{P}$ and $\mathrm{K}$ content. The required quantity of samples was weighed out accurately and was subjected to acid extraction and N, P and K content was determined. Nitrogen content in digested plant material was determined by micro kjeldhal method as described by AOAC (1995) [1]. Phosphorus and potassium content was determined by Vanadomolybdo phosphoric yellow colour method described by Koenig and Johnson (1942) and flame photometric method suggested by Jackson (1973).

Data were analyzed using analysis of variance (ANOVA) to evaluate the differences among treatments while the means were separated using the least significant difference (LSD) test at the $5 \%$ level of significance.

\section{Results and Discussion Effect on weeds}

Cover crop of Sesbania aculeata followed by green residue mulch recorded lesser weed density and weed biomass as compared to no mulching. However, it was on par with rice residue mulch in 2017. No mulching recorded significantly maximum density and biomass of weeds during both the years. Among weed management practices, penoxsulam 30 $\mathrm{g} /$ ha recorded significantly lesser density of weeds and weed biomass as compared to bispyribac $\mathrm{Na} 25 \mathrm{~g} / \mathrm{ha}$ alone and weedy during both the years. However, it was on par with two hand weeding during both the years. It was evident from the table 1 bispyribac Na $25 \mathrm{~g} / \mathrm{ha}+$ pyrazosulfuron $20 \mathrm{~g} / \mathrm{ha}$ and bispyribac $\mathrm{Na} 25 \mathrm{~g} / \mathrm{ha}$ were comparable with each other. Weedy recorded significantly maximum density and biomass of weeds amongst all the weed management treatments. This might be due to cover crop might have reduced weed seed germination and later stages of crop weed growth might have been suppressed at early stages of crop growth. Yadav et al. (2010) ${ }^{[14]}$ also observed that penoxsulam at $25 \mathrm{~g} / \mathrm{ha}$ as preemergence (3 DAT) and $22.5 \mathrm{~g} / \mathrm{ha}$ as post-emergence (10-12 DAT) application provided satisfactory control of all types of weeds.

Perusal of data revealed that mulching caused significant variations in nitrogen, phosphorous and potassium content in weeds. Significantly lowest nitrogen, phosphorous and potassium content in weed was found in cover crop of Sesbania aculeata followed by green residue mulch as compared to no mulching and it was statistically on par with rice residue mulch, whereas, no mulching recorded highest nitrogen content in weed during both the years (Table 2). It is evident from table 2 penoxsulam $30 \mathrm{~g} / \mathrm{ha}$ recorded significantly lesser nitrogen, phosphorous and potassium content in weed as compared to weedy and during both the years. However, it was on par with two hand weeding during both the years and also it was statistically comparable with bispyribac Na $25 \mathrm{~g} / \mathrm{ha}+$ pyrazosulfuron $20 \mathrm{~g} / \mathrm{ha}$ in 2017 . 
Weedy recorded significantly highest nitrogen, phosphorous and potassium content in weed amongst all the weed management treatment during both the years of experimentation.

\section{Effect on crop}

Mulching did not affect the plant height during both the years. Penoxsulam $30 \mathrm{~g} / \mathrm{ha}$ recorded significantly higher plant height as compared to weedy during both the years. However, it was on par with two hand weeding at all the stages of observation. Further, bispyribac Na $25 \mathrm{~g} / \mathrm{ha}+$ pyrazosulfuron $20 \mathrm{~g} / \mathrm{ha}$ and bispyribac Na $25 \mathrm{~g} / \mathrm{ha}$ alone had at par plant height at harvest. Weedy recorded significantly minimum plant height amongst all the weed management treatment at all the stages of observation during both the years of experimentation.

Critical analysis of data in table 2 revealed that, significantly higher no. of tillers $/ \mathrm{m}^{2}$ was recorded with cover crop of Sesbania followed by green residue mulch as compared to rice residue mulch and no mulching treatment during both the years. This might be due to vigorous growth of Sesbania and availability of green residue mulch on the field. Joseph (1998) reported that incorporation of Sesbania aculeata in rice on 35 DAS uniformly increased the productive tillers/ $\mathrm{m}^{2}$ and 1000 grain weight. Penoxsulam $30 \mathrm{~g} / \mathrm{ha}$ recorded higher value of number of tillers $/ \mathrm{m}^{2}$ as compared to tank mix bispyribac $\mathrm{Na}$ $25 \mathrm{~g} / \mathrm{ha}+$ pyrazosulfuron $20 \mathrm{~g} / \mathrm{ha}$, bispyribac $\mathrm{Na} 25 \mathrm{~g} / \mathrm{ha}$ alone and weedy at all the stages of observation during both the years (Table 1). This might be attributed to broad spectrum and complete killing of weeds due to penoxsulam leading to a higher weed control. Singh (2002) ${ }^{[13]}$ reported that the weed density in weed control treatments was lower thus offer less competition to rice plants which in turn benefitted the number of shoots and panicles $/ \mathrm{m}^{2}$. Similar findings were reported by Sansa et al., (2016) ${ }^{[12]}$.

Yield attributes of the plant is the resultant of the vegetative growth of the plant which collectively determines yield. Appraisal of data in table 2 revealed that, cover crop of Sesbania aculeata followed by green residue mulch recorded significantly higher panicle length as compared to no mulching during both the years. However, it was on par with rice residue mulch during both the years of study. Weed management treatments also caused significant variations in panicle length. Penoxsulam $30 \mathrm{~g} / \mathrm{ha}$ recorded longer panicle as compared to bispyribac $\mathrm{Na} 25 \mathrm{~g} / \mathrm{ha}$ alone and weedy during both the years. However, it was on par with two hand weeding and bispyribac Na $25 \mathrm{~g} / \mathrm{ha}+$ pyrazosulfuron $20 \mathrm{~g} / \mathrm{ha}$. Further analysis of data in table evidenced that bispyribac $\mathrm{Na}$ $25 \mathrm{~g} / \mathrm{ha}$ alone and tank mix bispyribac $\mathrm{Na} 25 \mathrm{~g} / \mathrm{ha}+$ pyrazosulfuron $20 \mathrm{~g} / \mathrm{ha}$ were at par with each other in 2018 , whereas, weedy recorded significantly shortest panicle during both the years of study. Test weight did not differed significantly due to mulching as well as weed management treatments. The highest panicle length might be due to better growth of plant with the availability of efficient utilization of nutrient and available resources with less weed competition in cover crop of Sesbania aculeata followed by green residue mulch which increased number of tillers (Table 2) which ultimately leads to highest panicle length.

Cover crop of Sesbania aculeata followed by green residue mulch recorded significantly maximum production efficiency as compared to no mulching and it was on par with rice residue mulch during both the years of study. Further analysis of data revealed that penoxsulam $30 \mathrm{~g} / \mathrm{ha}$ recorded significantly higher production efficiency as compared to bispyribac Na $25 \mathrm{~g} / \mathrm{ha}+$ pyrazosulfuron $20 \mathrm{~g} / \mathrm{ha}$, bispyribac $\mathrm{Na} 25 \mathrm{~g} / \mathrm{ha}$ alone and weedy during both the years, however, it was on par with two hand weeding. Tank mix bispyribac Na $25 \mathrm{~g} / \mathrm{ha}+$ pyrazosulfuron $20 \mathrm{~g} / \mathrm{ha}$ recorded significantly higher production efficiency as compared to bispyribac $\mathrm{Na} 25$ $\mathrm{g} / \mathrm{ha}$ alone and weedy. Weedy recorded significantly minimum production efficiency amongst all the weed management treatment during both the years of experimentation. Higher production efficiency recorded under these treatment might be due to lower weed competition and higher grain yield.

Nitrogen, phosphorous and potassium content by crop as influenced by mulching and weed management treatments (Table 2). Data revealed that tested mulching as well as weed management treatments failed to cause any significant variations in total nitrogen, phosphorous and potassium content during both the years of study. Weed management treatments had significant variation in nitrogen, phosphorous and potassium content. All the weed management practices were on par with each other with respect to nitrogen content except bispyribac $\mathrm{Na} 25 \mathrm{~g} / \mathrm{ha}$ alone and weedy in 2017 and 2018 which was significantly inferior to other weed management treatments. This might be due to less weed competition in herbicide treated plots in comparison to weedy plots and more nitrogen utilization by crop which would increase nitrogen content. Lower values of $\mathrm{N}, \mathrm{P}$ and $\mathrm{K}$ content in weedy as compared to weed control treatments were also reported by Tala and Jena (2014). Increased nutrient content (Table 2) under these treatments was obviously owing to effective weed control both during initial and later stages of crop growth, leading to lesser competition for nutrients. Weed management treatments failed to cause any significant variations in phosphorus and potassium content during both the years of study.

Table 1: Effect of mulches and weed management treatments on weed density, weed biomass and nutrient content in weed in unpuddled transplanted hybrid rice

\begin{tabular}{|c|c|c|c|c|c|c|c|c|c|c|}
\hline \multirow[t]{2}{*}{ Treatment } & \multicolumn{2}{|c|}{$\begin{array}{c}\text { Weed density } \\
\left(\text { No. } / \mathrm{m}^{2}\right) \text { at } 40 \text { DAS }\end{array}$} & \multicolumn{2}{|c|}{$\begin{array}{c}\text { Weed biomass }\left(\mathrm{g} / \mathrm{m}^{2}\right) \\
\text { at } 40 \text { DAS }\end{array}$} & \multicolumn{2}{|c|}{$\begin{array}{c}\text { Nitrogen content in } \\
\text { weeds }(\%)\end{array}$} & \multicolumn{2}{|c|}{$\begin{array}{c}\text { Phosphorous content } \\
\text { in weeds }(\%)\end{array}$} & \multicolumn{2}{|c|}{$\begin{array}{l}\text { Potassium content } \\
\text { in weeds }(\%)\end{array}$} \\
\hline & 2017 & 2018 & 2017 & 2018 & 2017 & 2018 & 2017 & 2018 & 2017 & 2018 \\
\hline \multicolumn{11}{|c|}{ Mulching } \\
\hline No mulching & $\begin{array}{c}10.86 b \\
(140)\end{array}$ & $\begin{array}{c}12.59 \mathrm{c} \\
(171)\end{array}$ & $\begin{array}{l}13.92 b \\
(213)\end{array}$ & $\begin{array}{c}14.89 \mathrm{~b} \\
(261)\end{array}$ & $1.70 \mathrm{~b}$ & $1.77 \mathrm{~b}$ & $0.28 \mathrm{c}$ & $0.33 b$ & $0.51 \mathrm{~b}$ & $0.55 b$ \\
\hline $\begin{array}{l}\text { Cover crop of Sesbania } \\
\text { followed by surface mulch with } \\
\text { same residue }\end{array}$ & $\begin{array}{l}7.69 \mathrm{a} \\
(71)\end{array}$ & $\begin{array}{l}7.72 \mathrm{a} \\
(74)\end{array}$ & $\begin{array}{l}9.61 \mathrm{a} \\
(110)\end{array}$ & $\begin{array}{l}9.94 a \\
(118)\end{array}$ & $1.20 \mathrm{a}$ & $1.30 \mathrm{a}$ & $0.25 \mathrm{a}$ & $0.26 a$ & $0.37 \mathrm{a}$ & $0.39 \mathrm{a}$ \\
\hline Rice residue mulch(5 t/ha) & $\begin{array}{l}8.34 \mathrm{a} \\
(81)\end{array}$ & $\begin{array}{l}9.68 \mathrm{~b} \\
(110)\end{array}$ & $\begin{array}{l}10.53 \mathrm{a} \\
(128)\end{array}$ & $\begin{array}{c}11.49 \mathrm{a} \\
(159)\end{array}$ & $1.39 \mathrm{a}$ & $1.59 \mathrm{ab}$ & $0.27 b$ & $0.29 \mathrm{ab}$ & $0.42 \mathrm{ab}$ & $0.44 \mathrm{a}$ \\
\hline SEm \pm & 0.29 & 0.49 & 0.48 & 0.50 & 0.06 & 0.08 & 0.009 & 0.01 & 0.03 & 0.02 \\
\hline $\operatorname{LSD}(\mathrm{P}=0.05)$ & 1.14 & 1.93 & 1.90 & 1.98 & 0.23 & 0.30 & 0.04 & 0.05 & 0.10 & 0.08 \\
\hline \multicolumn{11}{|c|}{ Weed management } \\
\hline
\end{tabular}




\begin{tabular}{|c|c|c|c|c|c|c|c|c|c|c|}
\hline Weedy & $\begin{array}{c}16.06 \mathrm{c} \\
(261)\end{array}$ & $\begin{array}{c}17.84 \mathrm{c} \\
(318)\end{array}$ & $\begin{array}{c}19.48 \mathrm{c} \\
(384)\end{array}$ & $\begin{array}{c}22.19 \mathrm{c} \\
(508)\end{array}$ & $1.91 \mathrm{c}$ & $1.99 \mathrm{c}$ & $0.30 \mathrm{c}$ & $0.35 \mathrm{~d}$ & $0.59 \mathrm{c}$ & $0.62 \mathrm{~d}$ \\
\hline Two hand weeding at 20 and 40 & $\begin{array}{c}6.55 \mathrm{a} \\
(41)\end{array}$ & $\begin{array}{c}6.98 \mathrm{a} \\
(51)\end{array}$ & $\begin{array}{c}8.43 \mathrm{a} \\
(73)\end{array}$ & $\begin{array}{c}8.27 \mathrm{a} \\
(71)\end{array}$ & $1.12 \mathrm{a}$ & $1.22 \mathrm{a}$ & $0.23 \mathrm{a}$ & $0.22 \mathrm{a}$ & $0.33 \mathrm{a}$ & $0.35 \mathrm{a}$ \\
\hline DAT & $\begin{array}{c}8.29 \mathrm{~b} \\
(71)\end{array}$ & $\begin{array}{c}9.78 \mathrm{~b} \\
(99)\end{array}$ & $\begin{array}{c}10.96 \mathrm{~b} \\
(125)\end{array}$ & $\begin{array}{c}11.37 \mathrm{~b} \\
(133)\end{array}$ & $1.59 \mathrm{~b}$ & $1.75 \mathrm{~b}$ & $0.28 \mathrm{~b}$ & $0.32 \mathrm{c}$ & $0.48 \mathrm{~b}$ & $0.52 \mathrm{c}$ \\
\hline $\begin{array}{c}\text { Penoxsulam (30 g/ha) at 18 } \\
\text { DAT }\end{array}$ & $\begin{array}{c}6.48 \mathrm{a} \\
(44)\end{array}$ & $\begin{array}{c}7.15 \mathrm{a} \\
(75)\end{array}$ & $\begin{array}{c}8.28 \mathrm{a} \\
(74)\end{array}$ & $\begin{array}{c}8.80 \mathrm{a} \\
(82)\end{array}$ & $1.16 \mathrm{ab}$ & $1.28 \mathrm{a}$ & $0.26 \mathrm{ab}$ & $0.26 \mathrm{~b}$ & $0.35 \mathrm{a}$ & $0.37 \mathrm{a}$ \\
\hline $\begin{array}{c}\text { Bispyribac (25 g/ha) + } \\
\text { pyrazosulfuron (20 g/ha) at } 18\end{array}$ & $\begin{array}{c}7.43 \mathrm{ab} \\
(56)\end{array}$ & $\begin{array}{c}8.21 \mathrm{ab} \\
(55)\end{array}$ & $\begin{array}{c}9.61 \mathrm{ab} \\
(96)\end{array}$ & $\begin{array}{c}9.91 \mathrm{ab} \\
(102)\end{array}$ & $1.38 \mathrm{~b}$ & $1.52 \mathrm{~b}$ & $0.27 \mathrm{~b}$ & $0.30 \mathrm{c}$ & $0.41 \mathrm{~b}$ & $0.45 \mathrm{~b}$ \\
\hline DAT & 0.33 & 0.61 & 0.47 & 0.64 & 0.08 & 0.07 & 0.010 & 0.01 & 0.02 & 0.02 \\
\hline SEm \pm & 0.97 & 1.79 & 1.38 & 1.88 & 0.25 & 0.19 & 0.03 & 0.02 & 0.07 & 0.06 \\
\hline
\end{tabular}

Table 2: Effect of mulches and weed management treatments on growth attributes, yield attributes and nutrient content in crop in unpuddled transplanted hybrid rice

\begin{tabular}{|c|c|c|c|c|c|c|c|c|c|c|c|c|c|c|c|c|}
\hline \multirow[t]{2}{*}{ Treatment } & \multicolumn{2}{|c|}{$\begin{array}{l}\text { Plant height at } \\
\text { harvest }(\mathbf{c m})\end{array}$} & \multicolumn{2}{|c|}{$\begin{array}{l}\text { No. of tillers at } \\
\text { harvest }\left(/ \mathbf{m}^{2}\right)\end{array}$} & \multicolumn{2}{|c|}{$\begin{array}{c}\text { Panicle } \\
\text { Length }(\mathrm{cm})\end{array}$} & \multicolumn{2}{|c|}{$\begin{array}{c}\text { Test } \\
\text { weight }\end{array}$} & \multicolumn{2}{|c|}{$\begin{array}{l}\text { Production } \\
\text { efficiency } \\
\text { (kg/ha/day) }\end{array}$} & \multicolumn{2}{|c|}{$\begin{array}{l}\text { Nitrogen } \\
\text { content in } \\
\text { crop } \\
(\%)\end{array}$} & \multicolumn{2}{|c|}{$\begin{array}{l}\text { Phosphorous } \\
\text { content in } \\
\text { crop } \\
(\%)\end{array}$} & \multicolumn{2}{|c|}{$\begin{array}{c}\text { Potassium } \\
\text { content } \\
\text { in crop } \\
(\%)\end{array}$} \\
\hline & 2017 & 2018 & 2017 & 2018 & 2017 & 2018 & 2017 & 2018 & 2017 & 2018 & 2017 & 2018 & 2017 & 2018 & 2017 & 2018 \\
\hline \multicolumn{17}{|c|}{ Mulching } \\
\hline No mulching & 100.56 & 4.71 & $255.52 \mathrm{~b}$ & $246.26 \mathrm{~b}$ & $21.77 \mathrm{~b}$ & $20.90 \mathrm{~b}$ & 23.40 & 21.87 & $30.85 \mathrm{~b}$ & $29.31 b$ & 0.61 & .55 & 0.10 & .11 & 1.16 & 1.02 \\
\hline $\begin{array}{l}\text { Cover crop of } \\
\text { Sesbania followed by } \\
\text { surface mulch with } \\
\text { same residue }\end{array}$ & 108.80 & 105.65 & $321.63 \mathrm{a}$ & $312.46 \mathrm{a}$ & $25.59 \mathrm{a}$ & $24.56 \mathrm{a}$ & 23.76 & 22.20 & $41.66 \mathrm{a}$ & $40.92 \mathrm{a}$ & 0.62 & 0.62 & 0.12 & 0.13 & 1.19 & 1.22 \\
\hline $\begin{array}{c}\text { Rice residue mulch } \\
(5 \mathrm{t} / \mathrm{ha})\end{array}$ & 104.95 & 99.53 & $284.72 \mathrm{ab}$ & $265.24 b$ & $25.35 \mathrm{a}$ & $24.00 \mathrm{a}$ & 24.01 & 22.44 & $38.00 \mathrm{a}$ & $35.09 \mathrm{a}$ & 0.65 & 0.62 & 0.11 & 0.12 & 1.17 & 1.09 \\
\hline SEm \pm & 2.04 & 2.25 & 11.60 & 7.39 & 0.70 & 0.68 & 0.33 & 0.30 & 1.44 & 1.27 & 0.011 & 0.03 & 0.01 & 0.01 & 0.04 & 0.05 \\
\hline LSD (1) & $\mathrm{N}$ & NS & 45.57 & 29.03 & 2.76 & 2.67 & NS & NS & 5.66 & 4.98 & NS & NS & NS & NS & NS & NS \\
\hline \multicolumn{17}{|c|}{ Weed management } \\
\hline Weedy & $95.69 \mathrm{c}$ & $88.54 \mathrm{c}$ & $158.71 d$ & $109.04 d$ & 87.09 & 100.52 & 23.19 & 21.69 & $12.96 \mathrm{~d}$ & $12.5 \mathrm{~d}$ & $0.56 \mathrm{c}$ & $0.50 \mathrm{~b}$ & 0.10 & $0.12 \mathrm{~b}$ & 1.12 & 1.02 \\
\hline $\begin{array}{c}\text { Two hand weeding at } \\
20 \text { and } 40 \text { DAT }\end{array}$ & 109.91a & $108.34 \mathrm{a}$ & $350.23 \mathrm{a}$ & $351.16 \mathrm{a}$ & 8.49 & 10.06 & 24.30 & 22.70 & $47.13 \mathrm{a}$ & $45.6 \mathrm{a}$ & $0.65 \mathrm{a}$ & $0.64 \mathrm{a}$ & 0.12 & $0.11 \mathrm{a}$ & 1.17 & 1.17 \\
\hline $\begin{array}{c}\text { Bispyribac }(25 \mathrm{~g} / \mathrm{ha}) \\
\text { at } 18 \mathrm{DAT}\end{array}$ & $102.91 b$ & $98.23 b$ & $263.05 c$ & $261.72 \mathrm{c}$ & 25.74 & 36.26 & 23.33 & 21.80 & $34.33 \mathrm{c}$ & $32.7 \mathrm{c}$ & $0.60 \mathrm{~b}$ & $0.61 \mathrm{a}$ & 0.10 & $0.11 \mathrm{a}$ & 1.17 & 1.02 \\
\hline $\begin{array}{l}\text { Penoxsulam (30 } \\
\text { g/ha) at } 18 \text { DAT }\end{array}$ & $108.15 \mathrm{a}$ & $103.92 \mathrm{a}$ & $344.46 b$ & $345.30 \mathrm{a}$ & 13.15 & 17.23 & 23.97 & 22.40 & $46.85 a$ & $44.3 \mathrm{a}$ & $0.64 \mathrm{a}$ & $0.63 \mathrm{a}$ & 0.12 & $0.12 \mathrm{a}$ & 1.17 & 1.19 \\
\hline $\begin{array}{c}\text { Bispyribac }(25 \mathrm{~g} / \mathrm{ha}) \\
+ \text { pyrazosulfuron }(20 \\
\mathrm{g} / \mathrm{ha}) \text { at } 18 \mathrm{DAT}\end{array}$ & $107.18 \mathrm{ab}$ & $100.79 b$ & $319.98 b$ & $306.04 b$ & 17.69 & 25.23 & 23.83 & 22.25 & $42.90 \mathrm{~b}$ & $40.4 b$ & $0.66 \mathrm{a}$ & $0.61 \mathrm{a}$ & 0.11 & $0.12 \mathrm{a}$ & 1.24 & 1.16 \\
\hline SEm \pm & 2.352 & 2.384 & 10.68 & 8.38 & 4.27 & 3.36 & 0.33 & 0.31 & 1.31 & 1.10 & 0.015 & 0.03 & 0.01 & 0.01 & 0.05 & 0.06 \\
\hline $\operatorname{LSD}(\mathrm{P}=0.05)$ & 6.87 & 6.96 & 31.19 & 24.46 & 12.46 & 9.81 & NS & NS & 3.83 & 3.20 & \begin{tabular}{|l|}
0.04 \\
\end{tabular} & \begin{tabular}{|l|}
0.07 \\
\end{tabular} & NS & NS & NS & NS \\
\hline
\end{tabular}

\section{Conclusion}

On the basis of two years of experimentation, cover crop of Sesbania aculeata followed by green residue mulch with penoxsulam $30 \mathrm{~g} / \mathrm{ha}$ recorded lesser weed density and biomass higher growth attributes, yield attributes, production efficiency and nutrient content by crop under agro-climatic condition of Varanasi region.

\section{References}

1. AOAC. Official Methods of Analysis. 16th edn. Association of Official Analytical Chemists, Washington, DC, 1995.

2. Buhler, DD, Challenges and opportunities for integrated weed management, Weed Science, 2002; 50:273-280,

3. Fageria NK. Yield physiology of rice. Journal of Plant Nutrition. 2007; 30:843-879.

4. Gill JS, Walia SS, Gill RS. Direct seeded rice: an alternative rice establishment technique in north-west India: a review. International Journal of Advance Research. 2014; 2(3):375-386.

5. GRISP (Global Rice Science Partnership). Rice Almanac. Fourth ed. International Rice Research Institute, Los Baòos, Philippines. 2013, 283.
6. Haque ME, Bell RW, Islam MA, Rahman MA. Minimum tillage unpuddled transplanting: An alternative crop establishment strategy for rice in conservation agriculture cropping systems. Field Crops Research. 2016; 185:3139.

7. Ishaya DB, Dadari SA, Shebayan JAY. Evaluation of herbicides for weed control in three varieties of upland rice (Oryza sativa L) in the Nigeria Savannah. Crop protection. 2007; 26:1490-1495.

8. Islam AKMS, Hossain MM, Saleque MA. Effect of unpuddled transplanting on the growth and yield of dry season rice (Oryza sativa L.) in high barind tract. The Agriculturists. 2014; 12(2):91-97.

9. Jackson ML. Soil Chemical Analysis. Prentice Hall of India Pvt. Ltd., New Delhi. 1978, 498.

10. Johansen C, Haque ME, Bell RW, Thierfelder C, Esdaile RJ. Conservation agriculture for small holder rainfed farming: Opportunities and constraints of new mechanized seeding systems. Field Crops Research. 2012; 132:18-32.

11. Rahman M. Sustainable Weed Management for Unpuddled Transplanted Rice. Advances in Plants Agricultural Research. 2016; 5(2):00175. 
12. Sansa SK, Elizabeth Syriac K, Sheeja KR. Penoxsulam as post-emergence herbicide for weed control in transplanted rice. Indian Journal of Weed Science. 2016; 48(2):215-216.

13. Singh S, Singh $T$, Mehra SP. Efficiency of pyrazosulfuron- ethyl for weed control in transplanted rice (Oryza sativa). Extended Summaries, $2^{\text {nd }}$ Int. Agronomy Conference, New Delhi, India, 26-30. 2002; 2:928-929.

14. Yadav RA, Khan N, Dixit RN. Effect of establishment techniques and weed management practices on weed dynamics, yield attributing characters and yield of rice. Biennial Conference on "Recent Advances in Weed Science Research, Feb. 25-26, IGKV, Raipur (Chhattisgarh), 2010, 64 